\title{
There is only one Church! Albert Geyser's ecclesiology in Delayed Action
}

\begin{tabular}{|c|c|}
\hline \multicolumn{2}{|c|}{$\begin{array}{l}\text { Author: } \\
\text { Wim A. Dreyer }{ }^{1} \text { (D) }\end{array}$} \\
\hline \multicolumn{2}{|c|}{$\begin{array}{l}\text { Affiliation: } \\
{ }^{1} \text { Department of Church } \\
\text { History and Church Polity, } \\
\text { Faculty of Theology, } \\
\text { University of Pretoria, } \\
\text { South Africa }\end{array}$} \\
\hline \multicolumn{2}{|c|}{$\begin{array}{l}\text { Research Project Registration: } \\
\text { Project Leader: W.A. Dreyer } \\
\text { Project Number: } 77370920\end{array}$} \\
\hline \multicolumn{2}{|c|}{$\begin{array}{l}\text { Description: } \\
\text { This research is part of the } \\
\text { research project, 'Justice and } \\
\text { Human Dignity. A Reformed } \\
\text { perspective', directed by } \\
\text { Dr W. Dreyer, Department of } \\
\text { Church History and Church } \\
\text { Polity, Faculty of Theology, } \\
\text { University of Pretoria. }\end{array}$} \\
\hline \multicolumn{2}{|c|}{$\begin{array}{l}\text { Corresponding author: } \\
\text { Wim Dreyer, } \\
\text { wim.dreyer@up.ac.za }\end{array}$} \\
\hline \multicolumn{2}{|c|}{$\begin{array}{l}\text { Dates: } \\
\text { Received: } 19 \text { Apr. } 2017 \\
\text { Accepted: } 20 \text { May } 2017 \\
\text { Published: } 30 \text { June } 2017\end{array}$} \\
\hline \multicolumn{2}{|c|}{$\begin{array}{l}\text { How to cite this article: } \\
\text { Dreyer, W.A., 2017, 'There is } \\
\text { only one Church! Albert } \\
\text { Geyser's ecclesiology in } \\
\text { Delayed Action', HTS } \\
\text { Teologiese Studies/ } \\
\text { Theological Studies 73(1), } \\
\text { 4598. https://doi.org/ } \\
\text { 10.4102/hts.v73i1.4598 }\end{array}$} \\
\hline \multicolumn{2}{|c|}{$\begin{array}{l}\text { Copyright: } \\
\text { (C) 2017. The Authors. } \\
\text { Licensee: AOSIS. This } \\
\text { is licensed under the } \\
\text { Creative Commons } \\
\text { Attribution License. }\end{array}$} \\
\hline \multirow{2}{*}{ 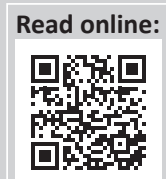 } & \\
\hline & $\begin{array}{l}\text { Scan this QR } \\
\text { code with your } \\
\text { smart phone or } \\
\text { mobile device } \\
\text { to read online. }\end{array}$ \\
\hline
\end{tabular}

A.S. (Albert) Geyser was professor of New Testament at the University of Pretoria from 1946 to 1961, when he accepted an appointment at the University of the Witwatersrand. He was one of the most active and outspoken critics of apartheid and played a leading role in the establishment of the Christian Institute and the appointment of Beyers Naude as the first director of the Institute. However, Geyser received very little attention either in church history or in the history of South Africa. This contribution, presented as the Third A.S. Geyser Commemorative Lecture at the University of Pretoria, reflects on Geyser's ecclesiology. It is quite remarkable that Geyser chose ecclesiology as point of entry into the discourse on apartheid. He engaged in fundamental theological criticism of segregation in church and state based on his understanding of the unity of the church in Christ and a humanity unified under the kingship of Christ.

\section{Introduction}

Prof. Dr A.S. (Albert) Geyser (1918-1985), alumnus and professor in New Testament (1946-1961) of the University of Pretoria, is rarely mentioned in connection with the struggle against apartheid. In fact, one is often led to believe that theologians and clergy of Afrikaans churches were unanimous in their support of apartheid, with a few exceptions like Bennie Keet, Ben Marais and Beyers Naude (Coetzee \& Conradie 2011:338). This was not the case. During the 1960s hundreds of Afrikaans clergy voiced their concerns, which ranged from mild reservations to outright rejection of apartheid.

Since the 1990s many articles in journals, chapters in books and postgraduate studies highlighted the role of Afrikaans theologians in the struggle against apartheid. As to be expected, this renewed appreciation came mostly from Afrikaans academics. However, wider recognition of the critical voice of Afrikaans theologians is growing, for instance, the contribution of Prince Mashele in Sowetan Live (01 May 2015) where he says the following of Albert Geyser:

Here was a white man, an Afrikaner by blood, adhering obstinately to a biblical truth that essentially shattered the religious foundations of Afrikanerdom - his very own being. It would indeed be difficult to know the extent to which black anti-statue crusaders of our time value truth. But it is easy to understand why white people have built no monument to Geyser. Could it be that those who are busy defacing statues are themselves not different from the very statues they seek to eradicate? True virtue is not when a man defends his own interests, but when he endangers his life in defence of others. This is precisely what Geyser did. It is time for us, black people, to wage a 'Geyser must rise' campaign to protect the legacy of a white man who proclaimed that blacks were human at a time when such a basic truth was heresy. (Mashele 2015: n.p.)

The fact is that there were many more like Geyser, especially during the non-violent phase of the struggle against apartheid which ended in the early 1960s. The turn from non-violent to violent resistance created much controversy which alienated many (see, for instance, Zunes 1999). Afrikaans theologians in general did not support the armed struggle or political violence. Their criticism was mostly deconstructing and opposed the theological and moral justification of apartheid. Several theologians (like Geyser), who were ordained ministers of the Nederduitsch Hervormde Kerk van Afrika (NHKA) [Netherdutch Reformed Church in Africa] and taught at various universities, resisted segregation in church and state as well as the theological justification of apartheid.

These critics included Old Testament scholars of the University of Pretoria such as Adrianus van Selms (1906-1984), Casper Labuschagne (1929-) and Jimmy Loader (1945-). Van Selms was a legend

Note: This was delivered during the third A.S. Geyser Commemorative Lecture by the author on 30 March 2017 at the University of Pretoria as part of the centenary celebrations of the Faculty of Theology. 
in his own lifetime, and posthumously honoured at the centenary celebrations of the University of Pretoria as one of its hundred greatest academic achievers. Labuschagne had to leave his position at the University of Pretoria and started teaching at the University of Groningen (1967-1991), where he still lives. Loader moved to the University of South Africa and then to Vienna. He is the Dean Emeritus of the Protestant Theological Faculty of the University of Vienna and Professor Ordinarius in Old Testament Studies and Biblical Archaeology at the same institution (see Van Aarde \& Dreyer 2013). He is still serving as minister of the Afrikaans-speaking congregation in Vienna.

Other theologians of the NHKA critical of racial policies were Prof. Dr J.A.A.A. Stoop and Prof. Dr B.J. van der Merwe (both lecturers at the University of South Africa). Van der Merwe taught Semitic Languages and Old Testament (see Venter 1999 for a biography). Stoop was a well-known church historian with extensive knowledge of early Patristic writings. He completed his doctoral studies at the University of Leiden under the supervision of Prof. Dr J.N. Bakhuizen van den Brink. In his dissertation, he discussed Augustine's views on the deificatio hominis and its implications for Christian anthropology (imago Dei) and ecclesiology. The dissertation (Stoop 1952) was published in Leiden and received much attention, even in Roman Catholic publications. ${ }^{1}$ Looking at the content of the dissertation, especially the section on ecclesiology (Stoop 1952:58-66), one could expect that Stoop would be critical of segregation in church and state. More explicitly, Stoop (1952:65) is of the opinion that the unity between Christ and the believer, the presence of Christ in the church, could never be limited to an intellectual enterprise, but is experienced in the liturgy, sacraments as well as the ethical life of every Christian. Through faith we know Christ is in us. That should determine our personal and ecclesial conduct.

To these (forgotten) names others could be added, not only academics but also ministers who served in various congregations. During the last three decades the name of Prof. Dr A.G. van Aarde stands out, as well as current members of the Faculty of Theology at the University of Pretoria. $^{2}$

During the 1960s Geyser and 10 other theologians published a booklet with the title Vertraagde Aksie, reprinted in English under the title Delayed Action (Geyser 1960). ${ }^{3}$ The theological essays in Delayed Action, in a direct or indirect manner, criticised the apartheid policies as well as the way Afrikaans churches supported these policies. The authors, all ordained ministers of the three Afrikaans 'sister churches', were A.S. Geyser, A. van Selms, M.J. Redelinghuys and J. Stutterheim (NHKA); B.B. Keet, B.J. Marais, G.C. Oosthuizen, J.A. van

\section{See, for instance, Studia Catholica 28/4, October 1953.}

2.See, for instance, the public declaration of five theologians against apartheid published in Beeld on 12 March 2009.

3.A translation was published with the title Delayed Action. In this contribution, worked with the original Afrikaans version, but I will refer to it as Delayed Action.
Wyk and G.J. Swart (Nederduitse Gereformeerde Kerk); as well as H. du Plessis and C. Hattingh (Gereformeerde Kerke van Suid Afrika). This publication appeared in the aftermath of the Sharpeville massacre, while preparations for the Cottesloe Consultation of the World Council of Churches were in its final stages.

In this lecture, Geyser's contribution to Delayed Action is discussed. Geyser chose as his topic the unity of the church as witness to the world. It is important to note that Geyser, with the other authors of Delayed Action, chose to enter the discussion on justice in South Africa from the perspective of ecclesiology. They were convinced that a Biblical and evangelical understanding of the church would in itself be sufficient to create a fundamental awareness amongst South African Christians that the calling and responsibilities of the church is in promoting justice and human dignity.

\section{Context of Delayed Action}

Before we look at the content of Geyser's contribution in Delayed Action, it is important to understand the context of Delayed Action. One of the contextual sources available to us is the newspapers of the time which carried many articles on Geyser and other theologians' criticism of apartheid. During the period 1960-1968 C.J. Labuschagne (mentioned above) collected hundreds of newspaper clippings related to the events surrounding Geyser and other Afrikaans theologians' opposition to apartheid. On a visit to Labuschagne in Groningen during 2014, he gave three volumes of clippings into my care, which I subsequently deposited in the church archives. ${ }^{4}$ From these clippings the hostile environment in which opponents of apartheid found themselves during the 1960s is evident, even to the extent that Geyser was regarded as a public enemy. It is also known that Geyser received several death threats. It is a stark reminder of another theologian of the University of Pretoria and apartheid critic, Prof. Johan Heyns, who was assassinated in his house. Severe criticism was levelled against Geyser in the media, coming from journalists, churches and the general public. Despite this, Geyser did not hesitate to make his views known to the general public.

Geyser often used public media to make his views known. This started much earlier than 1960 but became more intense in the wake of the events following Sharpeville (21 March 1960), especially when the government invoked the Illegal Organisations Act as well as the Public Security Act of 1953 which gave government extensive powers to curb public violence. One of the best and most lucid contributions of Geyser was an article which appeared in a special edition of Weekblad (see Labuschagne 2014:Vol. I, 1). Geyser was alarmed by the multiplication of security and racial laws and the draconian way in which they were applied. He points out that law and justice are not synonymous or the same thing. A strict application of law and order does not constitute justice;

4.The unpublished volumes of newspaper clippings will be referenced (in example) as 'Labuschagne 2014 Vol. I:' with page number and if known, the original author. In most instances, the author is indicated only as 'Staff Reporter' 
it rather fosters a climate where justice is suppressed. He distinguishes between a 'wetstaat' and a 'regstaat'. He was of the opinion that South Africa had turned into a state which was not built on justice but rather on an extensive system of laws, strict implementation of these laws and harsh maintenance of order by the police. He highlights the attempt of government (which failed) to establish a 'High Court', consisting of parliamentarians, as a clear attempt of government to replace rule of law exercised by an independent judiciary with an institution which would give government absolute power. He goes as far as to compare the state of affairs with the loss of justice in Germany under the leadership of Adolf Hitler. He even reminds the public that some of the current political leaders were, just a few years previously, still admirers of Hitler. He warned the public that the South African government was moving in the direction of a dictatorship. This obviously did not go down well with politicians, church leaders and the public alike.

Hendrik Vorster reported in the Sunday Times (20 November 1960) that:

350 dominees of the three Afrikaans churches in the Transvaal have been meeting in secret over the past six months in Johannesburg and Pretoria to discuss the government's apartheid policy - and the effects of the policy on the work of the Church. (see Labuschagne 2014:Vol I, 6)

Prof. Ben Marais, church historian in the Faculty of Theology at the University of Pretoria, told the reporters that during those meetings a very serious study of apartheid and its effect on the church was conducted. According to Marais, 'they were deeply uncertain about the future of the Christian Church and sought a solution to the crisis which the Church today faces'. The reporter (Vorster) 'reveals' that the publication of Delayed Action was a direct result of these consultations which took place over a period of 6 months.

\section{According to Vorster, Albert Geyser told him that:}

many of the aspects of apartheid as they affect the Church have caused deep anxiety among churchmen in South Africa... Now individual theologians have, for the first time [in Delayed Action] openly expressed their anxieties and have analysed the problems facing the Church as we see them. (see Labuschagne 2014:Vol I, 6)

Vorster comes to the conclusion that not only is Delayed Action the first formal protest of Afrikaans theologians against apartheid, but it also 'constitutes the biggest single challenge to apartheid which yet faced the Government'. The seriousness of this threat could not be underestimated because it came from the very heart of the Afrikaner establishment - 350 dominees from the Afrikaans churches.

These sentiments were also articulated by Prof B.B. Keet (1885-1974), lecturer in Dogmatics at the Stellenbosch Seminary. According to the journalist, Keet said:

The apartheid legislation of the past ten or twelve years reflects clearly a progressive curbing of the rights and privileges of our
non-European population, with all the misery and frustration which accompanies such a step. (see Labuschagne 2014:Vol. I, 6)

Keet studied in Princeton and completed his doctoral studies at the Free University of Amsterdam in 1914 with a thesis in Dutch on De Theologie van Ernst Troeltsch (see De Beer 1992). Keet, while resisting apartheid, was at the same time fighting for the rights of Afrikaans and was instrumental in the translation of the Bible into Afrikaans (1933).

On 21 November 1960, the Transvaler published an article in which a question was asked whether rebellion is brewing within the Afrikaans churches. In bold and large font, the two main culprits were announced to the readers of the newspaper: Die twee is Proff. Ben Marais en A.S. Geyser van die Fakulteit Godgeleerdheid aan die Universiteit van Pretoria (see Labuschagne 2014:Vol. I, 7a). During a meeting with the two theologians they informed the reporters that it is not true that a rebellion is brewing. Geyser and Marais made it clear that the purpose of Delayed Action was to assist churches in their Christian calling and in their public witness. As such, the book was not written for politicians or to promote rebellion in church and state. It was not intended as a political pamphlet, but rather as a theological document with political consequences. In his editorial comment, the editor of the Transvaler refrained from any commentary on the content of the book, but rather chose to warn the theologians that they are playing a dangerous game by talking to the English press which was per definition in opposition to the ideals of the Afrikaner people.

Public reaction to Delayed Action was not limited to the media. Public meetings were held, like the one Die Burger reported on (07 January 1961). During a public meeting in Brits, attended by approximately 3000 people, the theologians responsible for Delayed Action were severely criticised. The meeting was informed that the authors of Delayed Action were influenced by the ecumenical movement, which had no other purpose than promoting the demise of the Afrikaner people (see Labuschagne 2014:Vol. I, 7b). According to the column in Die Burger, Prof. Dr A.D. Pont, under loud ovation, further informed the meeting that the authors of Delayed Action 'in the name of the Church were demanding the suicide of the white people in South Africa'.

Politicians (like Senator J.H. Grobler) also entered the public debate by pointing out that political structures in other African countries collapsed after colonial powers were withdrawn, and in the process many white farmers had been murdered. The gist of his argument is that the authors of Delayed Action were propagating the murder of white people in South Africa (Die Transvaler, 25 November 1960; see Labuschagne 2014:Vol. I, 8). Grobler (and the general public) was very aware of the post-colonial political landscape in Arica. The Mau-Mau Uprising, for instance, was a conflict that took place in British Kenya between 1952 and 1960 during which thousands of Kenyans lost their lives in the most violent manner. Officially 11000 Kenyans lost their lives through the military actions of the British forces, although 
recent estimates place the number of deaths between 25000 and 90 000. Many deaths were the result of tribal conflict. During the 8 years of conflict, 38 white farmers were murdered, a relatively small number within the larger context, but enough to create the impression that white people were targeted in the struggle for political freedom and liberation. This rapidly changed many South African's views on race relations. Africa suddenly became a dangerous continent.

The same sort of criticism came from fellow academics at the University of Pretoria. The result was that Geyser (and others) became completely isolated, persona non grata and an enemy of the Afrikaner people. ${ }^{5}$

\section{Geyser's ecclesiology as articulated in Delayed Action}

So what did Geyser (and the other theologians) write in Delayed Action? What was so radical that it shook the foundations of the Afrikaner establishment? Two aspects must be pointed out before we look at the text in Delayed Action: (1) the influence of the ecumenical movement on Geyser and some of his co-authors and (2) the influence of Karl Barth's theology and actions during his resistance against the Nazi regime.

\section{The influence of the ecumenical movement}

The sub-title of Delayed Action was 'An ecumenical witness of the Afrikaans churches'. This sets the tone for the rest of the publication, which was to present a united front against apartheid coming from various individuals who were members of Afrikaans churches. The 'ecumenical' character of Delayed Action was twofold: On the one hand, it was intended as an ecumenical witness of Afrikaans theologians in South Africa and, on the other hand, the language and influence of the international ecumenical movement is manifest in various contributions.

In the foreword (pp. 3-4) of Delayed Action, the influence of ecumenical theology is quite clear. The editors (Geyser and Marais) explain how events in other countries, with surprising speed ('verbluffende vaart'), radically changed race relations in South Africa. Although these countries are not named, the authors most probably refer to Germany before the Second World War, the civil rights movement in the USA which received prominent news coverage in South Africa as well as the political changes in post-colonial Africa. The World Council of Churches was very much involved in these events, hosting several conferences which dealt with the political transformation, justice and democracy in African countries.

Geyser and Marais had personal contact with leaders in the international ecumenical movement. They were also aware of the views expressed by ecumenical consultations such as

5.In another contribution, the author told the story of Geyser's trial of heresy and his departure from the University of Pretoria (see Dreyer 2016).
Evanston, Illinois (1954), where racial policies such as apartheid were rejected contrary to the Christian message of reconciliation. In the introduction (p. 3), it is formulated as follows: 'In the Christian Church action means Christian witness, but then ecumenical witness. Based on this we are witnessing ... to fellow believers in our own land and in the whole world' (translated by the author).

It is also discussed in the introduction that the authors were asked to write something about the nature of the church and the calling of the church in a multi-racial country. In the last paragraph (p. 4), Delayed Action is called 'an ecumenical witness coming from the Afrikaans churches and as such should be regarded as pioneering work to counter the loss of (Christian) values in a time of conflict' (translated by the author). Delayed Action was intentionally positioned as an ecumenical witness with focus on the nature of the church, the unity of the church and the calling of the church, with specific reference to South Africa and the Afrikaans churches.

Delayed Action confronts the reader with the nature and mission of the church. The assumption is that if we understand the true nature of the church, it would have radical implications for the way the church speaks and engages with society. Ecclesiology and ethics are closely interrelated, as is clear from various documents of the World Council of Churches which appeared on a regular basis over the past few decades.

\section{The influence of Karl Barth ${ }^{6}$}

I am convinced the focus on ecclesiology was not only influenced by the ecumenical movement but also by the theology and actions of Karl Barth who, in his opposition to the Nazi ideology, placed much emphasis on a sound ecclesiology. The one aspect of this history which still needs to be investigated thoroughly is the way in which Karl Barth's theology and example influenced South African theologians' resistance to apartheid. For example, Prof. B.B. Keet was very much influenced by the theology of Barth (see De Beer 1992). Keet was deeply conscious of the German church struggle during the Nazi regime. In his contributions to the Kerkbode, he often referred to the role Barth played in resisting Hitler's National-Socialism (see Hoepfner 2004:39-46).

The influence of Barth, more specifically the struggle of the Bekennende Kirche against Hitler and the German Christian Movement as well as the Barmen Declaration, was also addressed by Ben Marais in several newspaper articles of the time (see Labuschagne 2014:Vol. I, 65). Marais also wrote a letter to Barth in which he asked nine questions related to apartheid and the theological justification of apartheid (see Hoepfner 2004:88-89). Barth's answer to these questions was mostly short, two-word sentences: 'No! Nazi-theology!'

Reading Geyser's text published in Delayed Action reminds us of a public lecture which Barth delivered on 22 July 1933,

6.Some of these aspects had been addressed in two previous contributions (see Dreyer 2015a; 2016) 
just before important church elections in Bonn. It was the time of Hitler's assumption of political power in Germany, and the German church stood before the daunting challenge of defining its own position within an extremely volatile and dangerous political environment. Barth pleaded with those present not to jeopardise the freedom of the gospel by voting for a direction which would enslave the church to nationalistic ideals. He points out that neither nature, history nor culture:

... macht die Kirche zur Kirche und nicht von daher ist die Kirche als Kiche zu verstehen. Evangelium heist ja nicht: der Mensch für Gott!, sondern ganz und gar und allein: Gott für den Menschen. Will die Kirche Kirche sein und bleiben, dann muss sie zäh und eifersüchtig über dieser Verkündigung wachen als über ihrem Wesen. (Barth 1933:6-7)

If 'the church wants to be church', it had to protect the freedom of the gospel which proclaims Jesus Christ as the only head and king of the church. Barth was convinced that whoever understood the true nature of the church would also understand that it had very real implications for the way in which the church conducts itself in the world. In that sense, the real nature of the church has direct implications for the church's role in society and politics.

In his contribution to Delayed Action Geyser echoes Barth's words: The fundamental challenge to the church is to be church ... He formulates this with reference to the early church fathers (Justin, Tertullian and the Apologists) as well as the persecution of the early church by explaining that the Roman emperors did not persecute the Christians because of what they said or did, but rather because of what they were, namely 'the church of Christ' (Geyser 1960:12). This distinction between the nature and mission of the church, what the church is and what the church does, is typical Barthian (and ecumenical) ecclesiology.

Barth used teaching opportunities at various institutions to raise the question of what the church's role should be in society, especially in light of the events taking place in Germany. During these lectures he often used the Apostolicum or the Nicene Creed as basis, explaining what the implications are if the church understands itself as una sancta catholica ecclesia. This is clear from the lectures Barth presented at the University of Utrecht (March 1935), in which he used the Apostolicum to address the main questions of doctrine, including ecclesiology. The lectures were published in shortened form after the Second World War (Barth 1946). Barth included a striking page at the start of this exposition of the Apostolicum: Under the heading '1935!' Barth lists the names of five German pastors who resisted the Nazi ideology and all ended up in jail. One (Karl Immer) died in 1944 of injuries sustained during his incarceration. This specific publication was well known amongst the lecturers at the University of Pretoria.

The Barthian influence on Geyser's opposition to apartheid again surfaced during a debate in the 1961 General Assembly of the NHKA. During the debate, which took 5 days to complete, Geyser mentioned that he showed the documents pertaining to racial segregation in church and state to Oscar Cullman and Karl Barth while on visit in Europe (NHKA 1961:28). Both rejected it outright.

\section{Analysis of Geyser's contribution in Delayed Action}

Geyser's ecclesiology and opposition to churches structured according to ethnic and language differences and divisions has been discussed before (see Van Eck 1995). Van Eck (1995:829830) points out that Geyser's ecclesiology underwent radical change in the period 1952-1960. He is of the opinion that Geyser's visits to the Netherlands, the University of Utrecht and contacts with the ecumenical movement in Europe had much to do with this change. Van Eck comes to the conclusion that Geyser's contribution as New Testament scholar lies primarily in the field of ecclesiology, more specifically the way in which the early church evolved and extricated itself from Judaism, moving from a particularistic Jewish sect to a universal community. This understanding of the New Testament and the church led Geyser to severe criticism of any particularistic church structure.

Geyser's contribution to Delayed Action could be regarded as a short summary of his ecclesiological vision as it developed over the previous decade. The Afrikaans title, 'Die Eerste Evangelie oor die Eenheid van Kerk as Christusgetuinenis' refers to the first gospel (the Gospel of Matthew). Geyser develops his argument based on texts in the Gospel of Matthew. It is clearly structured, without headings or break in argument. In terms of my own interpretation, the flow of Geyser's argument in Delayed Action could be structured as follows.

\section{Marturia (p. 12)}

In the introductory part of his contribution to Delayed Action, Geyser points out that the most important witness (marturia) of the church is not to be found in what it does (preaching, doctrine or the Christian life) but in its being. He illustrates this point with a historical overview of the persecution of the 'the people of the Way' (Ac 9:2; Geyser 1960:12). He points out that the earliest persecutors (Nero and Domitianus) of the church did not persecute the Christian church because of their teaching, but for the mere fact that they were members of the church. The Christians were persecuted not because of what they said or what they did, but because of what they were - the church of Christ. Whenever the church is true to its own nature and the integrity of the church stands foremost, the church as such becomes the most powerful witness to the gospel of Jesus Christ.

He points out (p. 12) that the early Christians regarded themselves as a tertium genus, a people distinguishable from both the Greco-Roman and the Jewish cultures. This genus or people transcended all cultural and political boundaries. It is this universality of the church which had been articulated in the Apostolicum. 


\section{Credo unam sanctam catholicam ecclesiam (pp. 13-14)}

Geyser points out that unam sanctam catholicam ecclesiam is often wrongly translated, by translating 'una' as an indefinite article. This undermines the essential unity of the church. ${ }^{7}$ Geyser follows Bakhuizen van den Brink in pointing out that 'una' should be translated as 'I believe one church'. There has always been just 'the' church. All Christians are one in Christ and this unity should become manifest in the church. Geyser further points out that the other essential qualities of the church ('sanctam' and 'catholicam') are fundamentally determined by 'unam'. The church is holy and catholic because of its unity in Christ.

The one holy church all over the world is the community of saints, a community which God called together to serve Him and each other. Geyser is of the opinion that the communio sanctorum implies an 'intentional, personal and lived unity' which becomes visible in the loving care they bestow on each other (p. 14).

\section{Kuriakon}

Geyser (1960:14) continues by explaining the word kuriakon as meaning 'what belongs to the Lord'. From this he comes to the conclusion that it is impossible to speak of an Afrikaans church, a Dutch church or a Bantu church. In the midst of ethnic, political and geographical divisions the church must be one, new humanity which belongs to God. From this it is quite clear that Geyser's ecclesiology stood diametrically opposed to segregation in church and state.

\section{Ekklesia}

Geyser (1960:14-16) then enters into a long discussion of the word ekklesia. It is at this point where the Gospel of Matthew $(18: 17 ; 16: 13-19 ; 10: 2 ; 26: 33-35 ; 18: 18)$ becomes central to his argument. He highlights the meaning of the word with reference to the gospels, early church fathers such as Chrysostomos, Augustine, Cyprian and even the thirdcentury Pope Callixtus. In his exegesis Geyser emphasises the communal character of the ekklesia of the church. The churches are those people, of all nations, who were called by the Lord and sent out by the Lord (Mt 28).

Geyser argues the question who 'the rock' is on which would build his church (Mt 16:13-19). Since Pope Callixtus (3rd century) the Roman Catholic view is that it refers to Peter and the succession of popes. Chrysostomos was of the opinion that 'the rock' did not refer to Peter but rather to his confession that Jesus is the Christ, a view which Luther subscribed to. Augustine regarded 'the rock' as Jesus Christ himself, a view to which Calvin subscribed. Cyprian was of the opinion that 'the rock' referred to the unity of the church, a view which Zwingli shared. Geyser was of the opinion that 'the rock' to

7.Surprisingly, Geyser added 'unam' here, which of course is not part of the textus receptus of the Apostolicum. It might be possible that he followed Van Niftrik receptus of the Apostolicum. It might be possible that he followed Van Niftrik (1949:178), or that he just wanted to push the issue of the unity of the church, or that he rather intended to work with the Nicene Creed which includes "unam" Whatever the case, he is wrong in his statement that unam sanctam catholicam ecclesiam dates to the second century. Historical research indicates that the article on the church was added to the Apostolicum at the end of the 4th century (see Dreyer 2015b). which Matthew 16 refers should not be limited to Peter, but rather includes the complete community of saints.

\section{Ecclesia apostolata}

For Geyser (p. 16), based on Matthew 16:18, the church is 'ecclesia apostolata or nothing'. Mission is not one of the functions of the church; it is the essential attribute of the church. The one church, which is the body of Christ, the temple of the Holy Spirit and the family of the Father which becomes visible in the sacrament of Holy Communion, can never be anything else than the church which Jesus sent out (Mt 28) to make people from all nations his disciples.

Geyser (1960:16-17) enters into a discussion of mission, where it is again evident that he followed Barth's understanding of mission, as articulated at the Brandenburg Mission Conference (1932) and again at the Willingen Mission Conference (1952). Barth was of the opinion that the church should not delegate its mission to mission organisations but should engage in mission itself, because the church is in essence apostolic. The church does not do mission; it is part of God's mission to the world and as such by nature apostolic (Scott 1977:15).

From this understanding of the church, Geyser (1960:22-23) enters into a sharp criticism of the establishment of ethnic churches via mission organisations or even the church itself. Geyser rejects the notion that the Great Commandment of Matthew 28 of 'go to all the nations' implies the establishment of ethnic churches. It rather points to the inclusivity of mission and the unity of the church. With reference to Jesus' prayer in John 17 he points out that ecclesial unity is the most powerful witness to the world of the love of God. Doing mission at 'an arm's distance' is contrary to the nature of the church and in contradiction to the unity of the church. He rejects the view that church unity is 'invisible'. It is the same criticism of ecclesiastic dualism, the distinction between the 'visible' and 'invisible' church of Christ, which we find in the ecclesiology of Karl Barth (1956, CD IV.1) when he writes.

For that reason the visible and invisible church are not two churches ... The one is the form and the other the mystery of one and the self-same church. The mystery is hidden in the form, but represented and to be sought in it. (p. 669)

\section{Qahal (pp. 18-21)}

Geyser points out that the early Christian writers used the Septuagint as source. In the Septuagint the Hebrew word qahal was translated with the word ekklesia. The qahal or ekklesia should be understood as the people of God. The disciples of the New Testament are the new Israel, the new people of God. Various New Testament texts make it quite clear that the new people of God are an inclusive community. Acts 15 tells the story of the first 'church council' which decided that non-Jews were part of the church. The people of God are not ethnically based, but come from all nations and all walks of life. The church is an open community where anybody irrespective of race or gender is welcome. 
Geyser then points out that the existence and growth of the church is the work of God, of Christ himself. Building up the church is not within our power. From this, he argues that the church may not and cannot 'establish' new churches, especially if these new churches are based on ethnic divisions. Establishing ethnically based churches is paramount to tearing the one body of Christ apart. Continuing in this spirit, Geyser is of the opinion that the term Christelik-nasionaal is a contradictio in terminis. Quoting the Heidelberg Catechism (p. 20), Geyser makes the point that the only comfort the church has is that it belongs to Christ and not to any ethnic group or political party or ideology. The comfort it brings, if the church belongs to Christ alone, is that not even the 'gates of hell' could conquer the church, because the church belongs to the One to whom all power on earth and heaven belongs.

\section{Kingdom of God (pp. 21-23)}

Geyser concludes with a discussion of what the kingdom of God entails as well as the relationship between church and kingdom. With reference to Matthew 16:19, Geyser points out that it is Christ himself who holds the keys to God's kingdom, but that he entrusted the church with great responsibility in terms of who is included in God's kingdom and who not. The only real question in terms of who is 'in' and who is 'out' is the confession of Peter: You are the Christ, the Son of the living God. That personal confession is the only and sufficient criterion to determine who is part of the heavenly kingdom. The church is responsible to accept and include every single person who confesses his or her faith in Christ. Our understanding of the church and the kingdom of God implies that the church does not have the authority to exclude anybody on the basis of race (and we should include gender, sexual orientation or any other external characteristic). Faith in Christ implies unity with Christ, a fact the church should respect.

Geyser concludes with a warning - it is dangerous if the church becomes so identical to the world in terms of ideology, political structures and divisions that it becomes difficult to distinguish between church and world. This will silence the prophetic voice of the church and render its proclamation empty and without meaning. It is extremely dangerous for the church to become gelykvormig [identical] to the world, to reduplicate political structures and ideologies into church practice. This warning is still relevant today.

\section{Conclusion}

From a contemporary perspective and with new exegetical insights one could criticise Geyser's explanation of the various terms, as discussed above. What stands out is his absolute conviction that the church belongs to God, that it should be united in Christ and that it must be obedient to its calling in witnessing to the world. It is clear that he rejects a particularistic understanding of the church, especially if that would imply racial segregation.
Geyser was a 'public theologian' par excellence. His ecclesiology as articulated in Delayed Action should be regarded as profound theological criticism of separate, ethnic churches as well as the church that became a mirror of what was happening in society (Geyser 1960:23). He called for an inclusive understanding of the church, a church with integrity, able to fulfil its prophetic calling to proclaim the gospel of Jesus Christ amidst terrible events which were shaking the foundations of society.

\section{Acknowledgements Competing interests}

The author declares that he has no financial or personal relationships which may have inappropriately influenced him in writing this article.

\section{References}

Barth, K., 1933, 'Für die Freiheit des Evangeliums', in Theologische Existenz Heute Heft 2, Kaizer Verlag, München.

Barth, K., 1946, Credo. Die Hauptprobleme der Dogmatik dargestellt im Anschluss de Apostolische Glabensbekenntnis, Evangelischer Verlag A.G., Zollikon.

Barth, K., 1956, Church dogmatics Vol. IV/1, G.W. Bromiley \& T.F. Torrance (eds.), transl. G.T. Thomson \& H. Knight, T \& T Clark, Edinburgh.

Coetzee, M.H. \& Conradie, E.M., 2011, 'Waar lê die diepste punt(e) van verdeling tussen apartheidsteologie en die kritiese stemme daarteen binne die NedGeref Kerk self?', NGTT 52(3 \& 4), 338-354.

De Beer, J.C., 1992, Prof. B.B. Keet (1885-1974) - leeraar en hoogleraar in die Nederduitse Gereformeerde Kerk. Ongepubliseerde DTh- verhandeling, Universiteit van Stellenbosch.

Dreyer, W.A., 2015a, 'In pursuit of justice: Albert Geyser's story as told by the media', Studia Historiae Ecclesiasticae 41(3), 184-197. https://doi.org/10.17159/24124265/2015/396

Dreyer, W.A., 2015b, "n Heilige, algemene kerk', HTS Teologiese Studies/Theological Studies 71(3), Art. \#2826, 1-8. https://doi.org/10.4102/hts.v71i3.2826

Dreyer, W., 2016, 'Heretic or rebel? The heresy trial of Albert Geyser', HTS Teologiese Studies/Theological Studies 72(4), a3745. https://doi.org/10.4102/hts.v72i4.3745

Geyser, A.S., 1960, 'Die Eerste Evangelie oor die eenheid van die kerk as Christusgetuienis', in Vertraagde aksie. 'n Ekumeniese getuienis vanuit die Afrikaanssprekende kerk, Geyser, A.S. \& Keet, B.B. (eds.), published by the editors, Pretoria, pp. 12-23.

Hoepfner, H.G., 2004, Die invloed van Karl Barth by die Nederduitse Gereformeerde Kerk 1928-1959. 'n Kerkhistoriese verkenning, ongepubliseerde MTh verhandeling, Fakulteit Teologie (Departement Ekklesiologie), Universiteit van die Vrystaat.

Labuschagne, C., 2014, Geyser newspaper clippings, vol. I, II \& III, NHKA Archives, Pretoria.

NHKA, 1961, Notule van die Algemene Kerkvergadering, NHKA Archives, Pretoria.

Mashele, P., 2015, 'Some whites deserve a statue', Sowetan Live, 1 May, viewed 20 September 2016, from http://www.sowetanlive.co.za/incoming/2015/05/01/ some-whites-deserve-a-statue

Scott, W., 1977, Die Missionstheologie Karl Barths, BrunnenVerlag, Basel.

Stoop, J.A.A.A., 1952, Die Deificatio Hominis in die Sermones en Epistulae van Augustinus, Drukkerij 'Luctor et Emergo', Leiden.

Van Aarde, A.G. \& Dreyer, Y., 2013, 'James Alfred Loader: 'n Huldeblyk aan 'n kritiessolidêre profeet in die eties teologiese tradisie/James Alfred Loader: A tribute to a critical-solidary prophet in the ethical theological tradition', HTS Theological Studies 69(1), Art. \#2029, 1-14. https://doi.org/10.4102/hts.v69i1.2029

Van Eck, E., 1995, 'J.H.J.A. Greyvenstein en A.S. Geyer se teologiese denke oor die volkskerkgedagte', HTS Theological Studies 51(3), 825-850. https://doi.org/ 10.4102/hts.v51i3.1440

Van Niftrik, G.C., 1949, De Belijdenis Aller Eeuwen, T. Wever, Franeker.

Venter, P.J., 1999, "n Kerklik-akademiese portret van B J van der Merwe (1926-1968): Deel Twee - Predikant en dosent', HTS Theological Studies 55(4), 1039-1076. https://doi.org/10.4102/hts.v55i4.1666

Zunes, S., 1999, 'The role of non-violent action in the Downfall of apartheid', The Journal of Modern African Studies 37(1), 137-169. 